\title{
The Mesozoic Tectonic Dynamics and Chronology in the Eastern North China Block
}

\author{
Quanlin Hou, ${ }^{1}$ Qing Liu, ${ }^{1}$ Hongyuan Zhang, ${ }^{2}$ Xiaohui Zhang, ${ }^{3}$ and Jun $\mathrm{Li}^{3}$ \\ ${ }^{1}$ Graduate University of Chinese Academy of Sciences, Beijing 100049, China \\ ${ }^{2}$ School of Earth Sciences and Resources, China University of Geosciences, Beijing 100083, China \\ ${ }^{3}$ Institute of Geology and Geophysics, Chinese Academy of Sciences, Beijing 100029, China \\ Correspondence should be addressed to Quanlin Hou, quhou@gucas.ac.cn \\ Received 12 January 2012; Revised 9 May 2012; Accepted 11 May 2012 \\ Academic Editor: Yu-Dong Wu
}

Copyright (c) 2012 Quanlin Hou et al. This is an open access article distributed under the Creative Commons Attribution License, which permits unrestricted use, distribution, and reproduction in any medium, provided the original work is properly cited.

\begin{abstract}
Mesozoic tectonic events in different areas of the eastern North China Block (NCB) show consistency in tectonic time and genesis. The Triassic collision between NCB and Yangtze results in the nearly S-N strong compression in the Dabie, Jiaodong, and west Shandong areas in Middle Triassic-Middle Jurassic. Compression in the Yanshan area in the north part of NCB was mainly affected by the collision between Mongolia Block and NCB, as well as Siberia Block and North China-Mongolia Block in Late Triassic-Late Jurassic. However, in the eastern NCB, compressive tectonic system in Early Mesozoic was inversed into extensional tectonic system in Late Mesozoic. The extension in Late Mesozoic at upper crust mainly exhibits as extensional detachment faults and metamorphic core complex (MCC). The deformation age of extensional detachment faults is peaking at 120-110 Ma in Yanshan area and at 130$110 \mathrm{Ma}$ in the Dabie area. In the Jiaodong area eastern to the Tan-Lu faults, the compression thrust had been continuing to Late Mesozoic at least in upper crust related to the sinistral strike slipping of the Tan-Lu fault zone.The extensional detachments in the eastern NCB would be caused by strong crust-mantle action with upwelling mantle in Late Mesozoic.
\end{abstract}

\section{Introduction}

In recent years, Mesozoic tectonic regime inversion is becoming one of the focuses in the studies of tectonic evolution and geodynamics. The Mesozoic tectonic dynamics process in the eastern North China is one of the most typical examples. EWtrending structural frame was transformed to the NE-NNEtrending structural framework and a compressive tectonic system to extensional tectonic system during Mesozoic. This intracontinental geodynamic process has attracted sight of geologists from China and around the world. Several hypotheses, such as long-distance effect of Pacific Plate [1], comprehensive constraints of the adjacent blocks (including the subducted and extinct Kula Plate, [2]), adjustment of the stress after the deep subduction of the Dabie area [3], largescale sinistral strike slip, mantle plume $[4,5]$, delamination of lithosphere, and/or continental root-plume tectonics, had been put forward during the last decade. These ideas, even though being of great benefit to the study on Mesozoic tectonic regime inversion, have neither given rise a complete theoretical framework nor concluded a uniform tectonic dynamics process. It should be noticed that China continent stands on the junction of three plates including the Tethyan oceans, the paleo-Asian ocean, and the paleo-Pacific ocean. The relative movement among the three plates, especially the Pacific plate which subducted NW warding beneath China continent, strongly affects China continent in the Mesozoic era. Many other important tectonic events, such as the continental deep subduction along the Dabie mountains, the lithosphere thinning of the eastern China, and the rapid uplifting of crust in western China, took place during a relative short period, although slightly different. With respect to the study of inversion process of tectonic regime in the eastern North China Block (NCB), the correlation and effect of the adjacent tectonic blocks should be considered, especially long-distance effect of the paleo-Pacific in the east and paleo-Tethyan in the west, and mantle upwelling would be considered as a reasonable tectonic model $[6,7]$. It is recognized that the Mesozoic tectonic dynamics and chronology is one key problem to understand the Mesozoic 
TABle 1: Mineral ${ }^{40} \mathrm{Ar}^{-39} \mathrm{Ar}$ data in the main shear zone of the eastern Dabie Orogenic Belt [11].

\begin{tabular}{lcc}
\hline Shear zone & Mineral & Weighted mean plateau age (Ma) \\
\hline Xiaotian-Mozitan shear zone & Biotite & $124.17 \pm 0.25$ \\
Shuihou-Wuhe shear zone & Biotite & $126.91 \pm 0.30$ \\
& Biotite & $190.59 \pm 0.42$ \\
Taihu-Mamiao shear zone & Hornblende & $197.41 \pm 0.46$ \\
& Biotite & $189.42 \pm 0.29$ \\
Susong-Qingshuihe shear zone & Biotite & $124.87 \pm 0.21$ \\
& White mica & $194.01 \pm 0.36$ \\
\hline
\end{tabular}

tectonic regime inversion in the eastern NCB. Three areas, the Dabie area and the Jiaodong area at the south margin and the Yanshan tectonic belt at the north part of the eastern NCB, would be discussed here to recognize the Mesozoic tectonic dynamics process in the eastern NCB.

\section{Mesozoic Tectonic Dynamics at the Dabie Area}

The Dabie area, located between NCB and Yangtze block in Early Mesozoic, is at the south margin of the eastern NCB. It is a key region to understand the Mesozoic tectonic regime inversion from compression to extension in the eastern NCB.

\subsection{Collisional Time Constraints during the Early Mesozoic.} The time range could be indicated by three aspects as follows. (1) The ultrahigh-pressure metamorphic assemblages started inversion at about $220-240 \mathrm{Ma}$ and cooled down to $300^{\circ} \mathrm{C}$ at $180 \mathrm{Ma}$ (time of the ${ }^{39} \mathrm{Ar}-{ }^{40} \mathrm{Ar}$ biotite clock start-up, $[8,9])$. (2) Geomagnetism studies indicate that visual polar migration curve of Hehuai basin, located at the south margin of NCB, had not been consistent with that of the Yangtze block until $159 \mathrm{Ma}$ [10], which indicated that the two blocks had jointed and the collision orogeny had completed by the time (159 Ma). (3) The sedimentation of the foreland molasse basin in the Badong-Echeng area in Hubei province began at Middle Triassic and finished in the Late Jurassic, which implies that the collisional orogeny developed from the Middle Triassic to the Late Jurassic. Therefore, the collisional orogeny of the Dabie area started at late stage of Early Triassic ( 240 Ma) and ended at Middle Jurassic $(\sim 180 \mathrm{Ma})$.

${ }^{40} \mathrm{Ar} /{ }^{39} \mathrm{Ar}$ dating of biotite and hornblende from the Shuihou-Wuhe shear zone and the Taihu-Mamiao shear zone, at the north and south sides of ultrahigh-pressure metamorphic zone in the Dabie area, respectively, was carried out (Table 1 after [11]). The results indicated that the first stage deformation occurred at about $190 \mathrm{Ma}$, probably reflecting the inversion and cooling of the ultrahigh-pressure metamorphic rocks in the postorogeny. It was suggested that, with the weakening of the orogenic activity and increasing of potential energy of gravity of the orogenic belt in the postorogeny, the principal compressional stress direction changed from horizontal to vertical, leading to the orogenic laxity or collapse, and the rapid inversion of the ultrahighpressure metamorphic rocks; then the nearly completion of collision in the Dabie area is about 190 Ma. Perhaps this $190 \mathrm{Ma}$ event extended to $160 \mathrm{Ma}$ in the late Jurassic because of the subduction of the paleo-Pacific plate [12].

2.2. The Late Mesozoic Extensional Detachment. The Northern Dabie metamorphic complex was identified as the crystalline metamorphic core of the Late Mesozoic extensional tectonics, which divided the Dabie area into two extensional tectonic systems, the north extensional tectonic system and the south extensional tectonic system (Figures 1 and 2).

2.2.1. The North Extensional Tectonic System. The identification of extensional crenulation cleavage $\left(\mathrm{C}^{\prime}\right)$ in the north detachment zones indicated that it is a complete extensional tectonic system, extending NE or NNE along the XiaotianMozitan faults where the principal extensional detachment zone was developed in the early Cretaceous (Figure 1). The shear strain $(\gamma)$ in the central part of the north detachment zone is up to about 2.6 and gradually decreased outward. The measurements of rock finite strains in the detachment zone indicated that the shear displacement is at least $56 \mathrm{~km}$.

2.2.2. South Extensional Tectonic System. The south extensional tectonic system is composed of, from north to south, the Shuihou-Wuhe shear zone, Taihu-Mamiao shear zone, and Susong-Qingshuihe shear zone, which could represent lower, middle, and upper detachment system, respectively, (Figure 1). Analysis of fabric and dislocation density of deformed quartz indicates that deformation temperature $\left(>700^{\circ} \mathrm{C}, 650-700^{\circ} \mathrm{C}\right)$ and differential stress (92 Mpa, 70$84 \mathrm{Mpa}$ ) descended from north to south in the south extensional tectonic system. The shear displacement of the upper detachment zone is at least $12 \mathrm{~km}$ by measurements of deformed rock finite strains. The directions of the extensional detachment are SSW, SSE, and/or S. The Flinn parameters $(K)$ of strain ellipsoids of the lower, middle and upper detachment systems are $0.01-0.1,1$, and $>7$ respectively, representing accordingly flattened strain $(K=$ 0.01-0.1), plane strain $(K \approx 1)$, and extensional strain $(K>$ 7) from north to south, which implies that the extensional detachment could be caused mainly by magma intrusions, consisting with the timing indicates. 


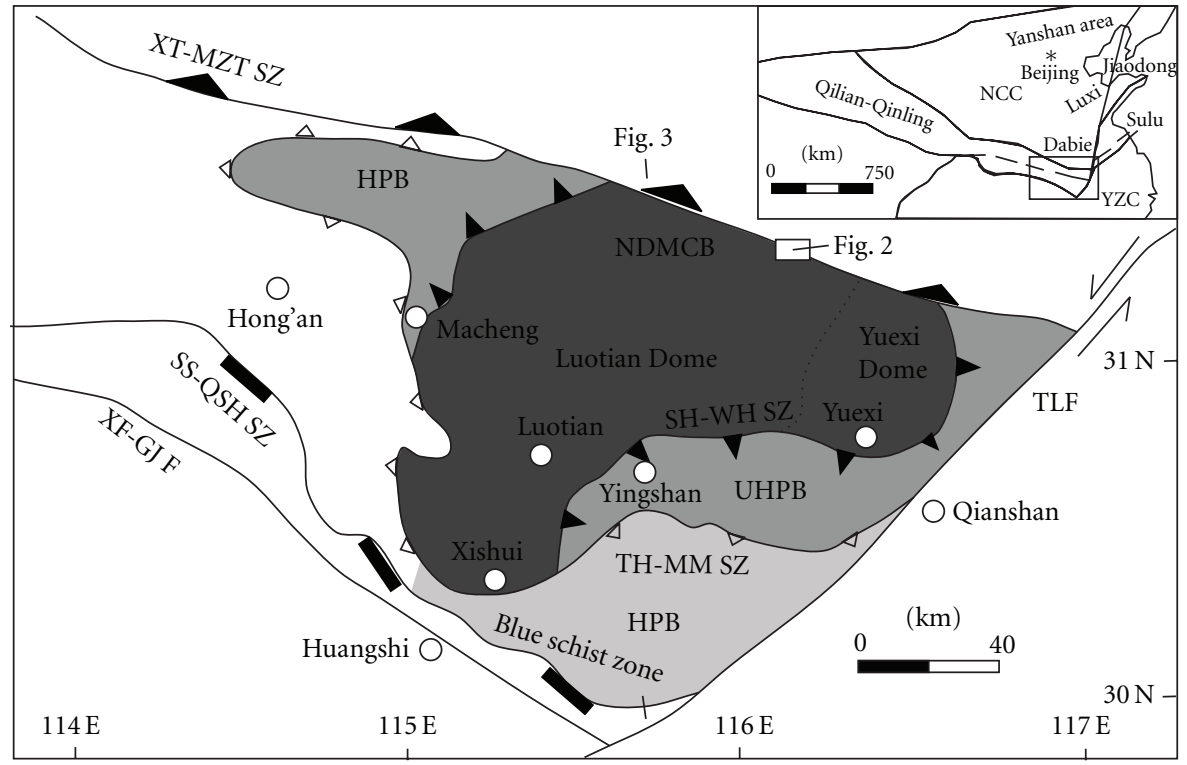

\section{NDMCl The North Dabie metamorphic belt \\ UHPB Ultrahigh-pressure belt \\ HPB High-pressure belt with blue schist zone}

FIGURE 1: Sketch map of Late Mesozoic main shear zones in eastern Dabie Orogenic Belt, Central China (after [13]). NCP: Northern China Block; YZB: Yangzi Block; NHEB: North Huaiyang metamorphic belt; NDMCD: Northern Dabie metamorphic complex belt; UHPB: ultrahigh pressure metamorphic belt; HPB: high-pressure metamorphic belt; SH-WH SZ: Shuihou-Wuhe shear zone; TH-MM SZ: TaihuMamiao shear zone; SS-QSH SZ: Susong-Qingshuihe shear zone; XT-MZT SZ: Xiaotian-Mozitan shear zone; TLF: Tancheng-Lujiang fault (Tanlu Fault); XF-GJF: Xiangfan-Guangji fault.
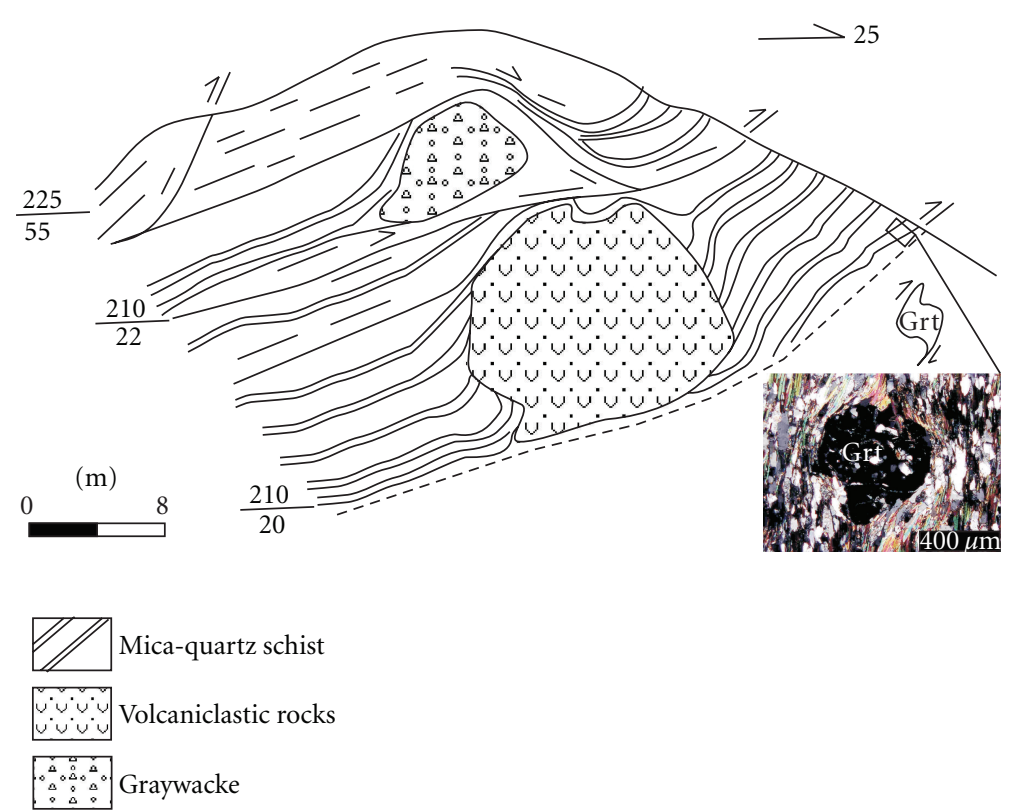

FIGURE 2: Late Jurassic volcaniclastic tectonite blocks were contained in mica-quartz schist $\left(\mathrm{Pt}_{2} \mathrm{n}\right)$, north extensional detachment zone, implying the extension shearing after Late Jurassic. The microstructure picture of mica-quartz schist is shown in the right below the profile, which possibly indicates a dextral rotation of kinematics in the profile. The phenomenon is located near the Zhutang Village of Youdian Town in Jinzhai County of the Anhui Province. 


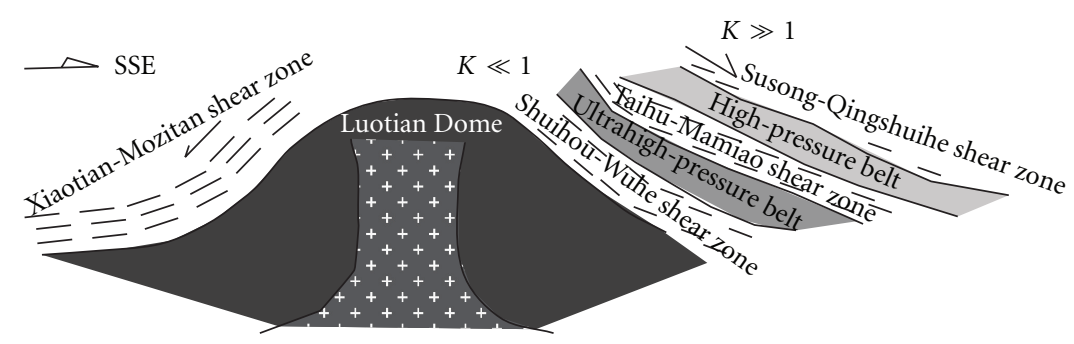

Figure 3: Extensional detachment model of Late Mesozoic, the Dabie Orogenic Belt.

\begin{abstract}
2.3. The Chronology Constraints on the Extensional Detachment. In north extensional detachment zone, the shear zone developing in the Xinyang Group $\left(\mathrm{Pt}_{2} \mathrm{n}\right)$ mica-quartz schist contains some allochthonous blocks from less than one meter to several meters in size of Late Jurassic volcaniclastic rocks and tuff. In addition, there are some field-scale harmonic recumbent folds in the Late Jurassic volcaniclastic rocks and the Late Proterozoic mica schist. Both Hong'an Group $(\mathrm{Pt})$ and the Yanshanian granite $\left(\mathrm{J}_{3}-\mathrm{K}_{1}\right)$ experienced extensional shear deformation together in the south extensional detachment system, which implies that the extensional detachment of both the south and north detachment systems took place after the Late Jurassic. The biotite and hornblende ${ }^{40} \mathrm{Ar} /{ }^{39} \mathrm{Ar}$ data from the north extensional tectonic system and in the Susong-Qingshuihe shear zone in the south detachment system reveal that the age of latter deformation is about $125 \mathrm{Ma}$ (Table 1, after [11] (Figure 1)), which should represent the time of extensional detachment after orogeny. As a whole, the extensional deformation in the Dabie area mainly took place about $120 \mathrm{Ma}$ ago.
\end{abstract}

2.4. Genesis of Extensional Detachment. At about 130$120 \mathrm{Ma}$, a little earlier than the detachment deformation age, numerous extensive granite and ultrabasic-basic plutons intruded into the Northern Dabie complex core. The ${ }^{40} \mathrm{Ar}$ ${ }^{39} \mathrm{Ar}$ and $\mathrm{Rb}-\mathrm{Sr}$ isotopic analyses of rocks in the North Dabie also recorded the time at about 110-130 Ma. These chronology data imply that the magma intrusion played a major rule during the extensional detachment, which were supported by the finite strain measure analysis of rocks in the south extensional tectonic system (Figure 3). In addition, the ductile deformation of the plagioclase and pyroxene of pyroxenite and gabbros (115-130 Ma) in the Northern Dabie metamorphic complex (mainly refer to the Luotian Dome) implies that they once reached granulite facies during deformation and then uplift to the surface. Therefore, it is concluded that voluminous magmatic emplacement and delamination of lithosphere in Early Cretaceous induced the rapid uplift of the Northern Dabie as the center area of UHPM rocks and extensional detachment on both sides of the Northern Dabie complex core. The intense denudation results in the voluminous sediments in the Hefei basin. The high-pressure and ultrahigh-pressure eclogites probably emplaced during this process on the basis of our data (Figure 3 ).

Additionally, the distributions of the platinum group elements (PGEs) in the ultramafic and/or mafic rocks $(\sim 120 \mathrm{Ma})$ in the Northern Dabie complex core show that their source regional upper mantle in Later Mesozoic enriched $\mathrm{PGE}(\mathrm{Pd} \approx 6.2 \mathrm{ppb}$ in mantle). The original mantle before Mesozoic, however, depleted the PGE (Pd $\approx 2.3 \mathrm{ppb}$ ), according to the PGE distribution in Bixiling ultramafic rocks (older than $240 \mathrm{Ma}$ ) in the Northern Dabie complex core $[14,15]$. The Later Mesozoic upper mantle with PGE enrichment in the Dabie area is supposed to be contaminated by about $8 \%$ Earth core materials, as the PGE contents in Earth core are much higher than in upper mantle [14, 15]. If thus, the enrichment mantle in the PGE must have been related to the Later Mesozoic extensional detachment in the Dabie area.

\section{Mesozoic Tectonic Dynamics in the Jiaodong Area}

The Jiaodong area, especially the eastern Jiaodong peninsula is located in the eastern terminal of the Dabie-Sulu ultrahigh pressure metamorphic belt, the eastern part of the south margin of the eastern NCB. As part of the collision orogenic belt between NCB and Yangtze block in Early Mesozoic, the eastern Jiaodong peninsula is significant in regional tectonic dynamics study in the eastern NCB.

The eastern Jiaodong peninsula can be divided into four lithotectonic units by four shear zones, the Shidao, Rongcheng, Mishan, and Mouping faults from SE to NW, respectively (Figure 4).

The Shidao shear zone is a broad ductile shear zone ( $>15 \mathrm{~km}$ in width) thrusting toward north and sinistral strike slipping in ENE-WSW direction. The total shear displacement is more than $90 \mathrm{~km}$, in which the strike displacement is at least $19 \mathrm{~km}$, the thrusting displacement $>88 \mathrm{~km}$, and the horizontal shrinkage $>85 \mathrm{~km}$, horizontal shrinkage ration about 68\% [18]. If Rongcheng, Mishan, and Mouping nappes were taken as an entirety, it turned about $25^{\circ}$ clockwise (Figure 4), similar to the Korea peninsula which turned $30.5^{\circ}$ clockwise [19].

The Rongcheng shear zone is a sinistral strike slipping and thrusting ductile shear zone dipping S or SSE in early stage (Figure 4). Different rocks, such as porphyritic granite $\left(\gamma_{5}^{3}, \sim 120 \mathrm{Ma}\right)$, granitic gneiss, and hornblende schists $\left(\mathrm{Pt}_{1}\right)$ of the Weideshan rock bodies, overrode one another as thrusting sheets (Figure 5), indicating a strong thrusting and sinistral strike slipping during late Yanshanian epoch. 

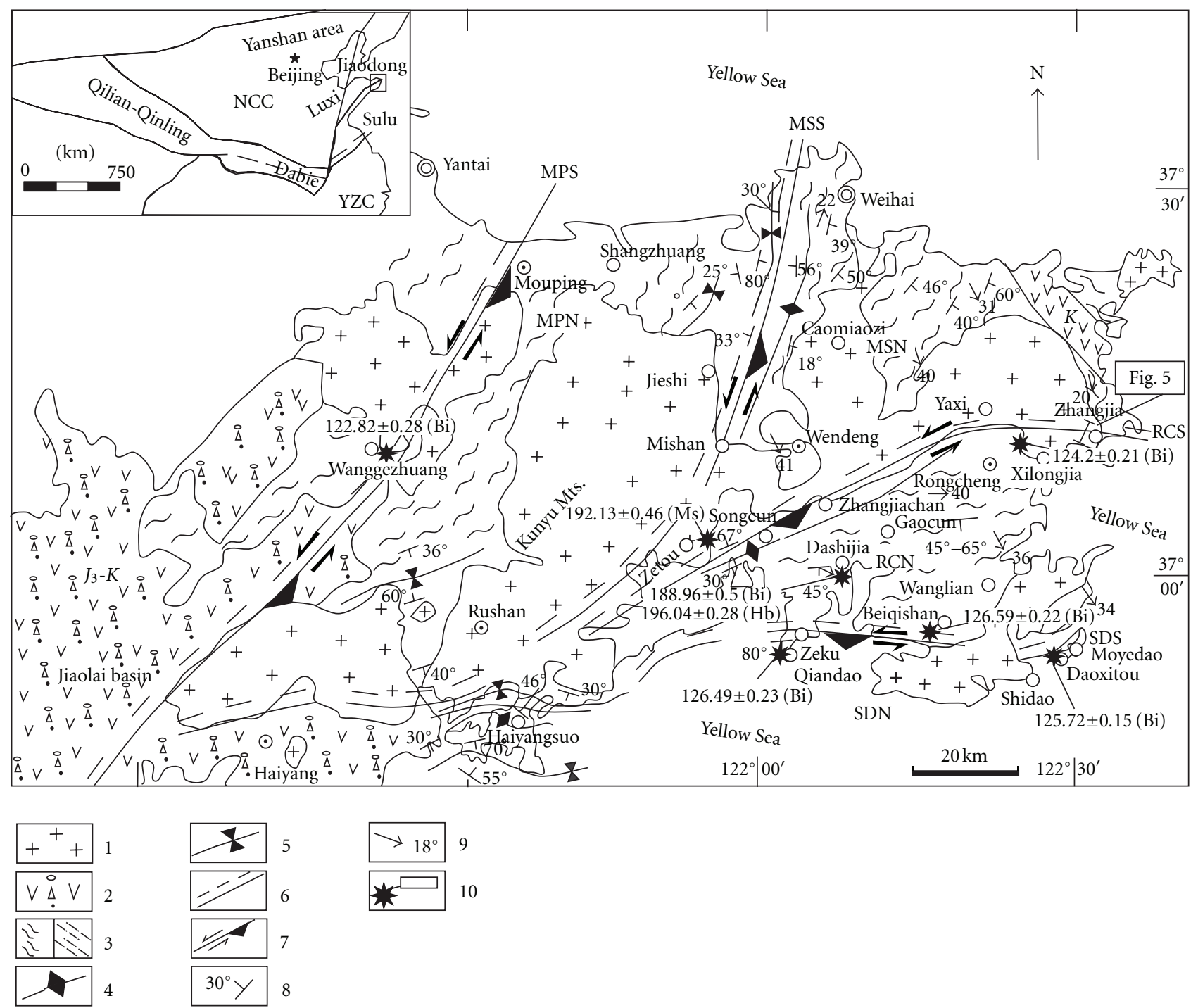

FIGURE 4: Geological map of the eastern Jiaodong peninsula (modified from [16, 17]). (Granite); (volcanic sedimentary rocks from Late Jurassic to Cretaceous); (gneiss rocks and mylonite zones); (syncline); (unticline); (brittle-ductile shear zones); (left lateral and reverse brittle shear sense); (layer occurrence); (lineation occurrence); (sample position and geochronological results). $\mathrm{F}_{1}, \mathrm{~F}_{2}, \mathrm{~F}_{3}, \mathrm{~F}_{4}$ : faults, namely, Shidao, Rongcheng, Mishan, and Mouping; I, II, II IV: nappes, namely, Shidao, Rongcheng, Mishan, and Mouping.

However, it could not be excluded that Rongcheng shear zone would experience extensional strike-slip nature at late stage.

The Mishan shear zone is an almost upright sinistral strike slipping fault zone striking NNE, in which a tectonoclastic rock belt of wide was formed. Rocks have a notable change across the fault. A few meters width of mylonite bands was observed in the fault zone, indicating that it could be a ductile shear zone in the early stages, and then was reconstructed later by brittle fractures. Therefore, it is difficult to identify the attitude and nature of the zone. However, it holds somewhat that the later stage of the shear zone was generally in agreement with the brittle shear zones in the Eastern Jiaodong peninsula.

The Mouping shear zone is a compression sinistral strikeslip fault striking NE-SW in steep dip. The shear zone expressed as a brittle-ductile tectonite belt $(20-30 \mathrm{~km}$ in width) and had extensional characteristics in late stage.
Mouping shear zone could be influenced by Tan-Lu faults, because similar tectonic behavior was proved in both the Mouping shear zone and the Tan-Lu fault zone, such as sinistral slip and long time of fault development.

The paleodifferential stress values of the Shidao, Rongcheng and Mouping shear zones are of $105 \mathrm{Ma}, 99 \mathrm{Ma}$, and $85 \mathrm{MPa}$, respectively, showing a decrease tendency from south to north. The strain measurement and the quartz cfabric analysis indicate that the deformation degree of those three shear zones decrease in order from south to north. The Flinn values $(K)$ of the strain ellipsoid range between 0.6 and 0.75 , implying flattening strain. Therefore, the thrusting in the Eastern Jiaodong peninsula should be from south to north in general.

${ }^{40} \mathrm{Ar} /{ }^{39} \mathrm{Ar}$ chronological analyses on the biotite and hornblende from the Shidao, Rongcheng, and Mouping shear zones (Table 2, [20]) indicated two groups, $\sim 190 \mathrm{Ma}$ and 

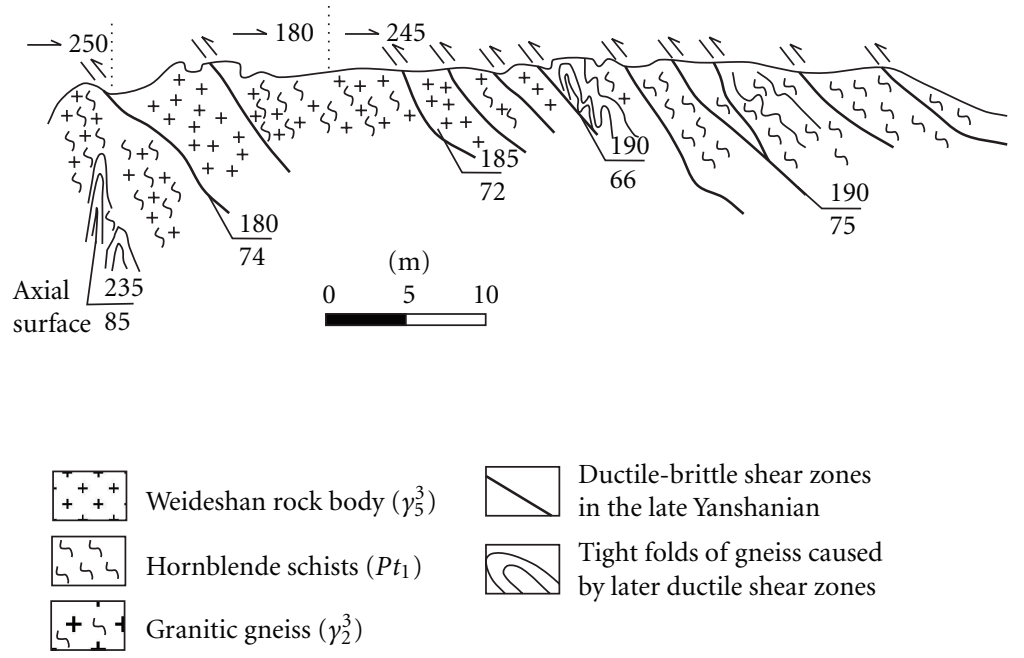

Figure 5: Structural outcrop sketch at Zhangjia, Rongcheng. At outcrop scale the porphyritic granite $\left(\gamma_{5}^{3}\right)$, granitic gneiss, and hornblende schists $\left(\mathrm{Pt}_{1}\right)$ of the Weideshan rock body were found to be overriding together as the style of thrusting sheets.

TABLe 2: ${ }^{40} \mathrm{Ar} /{ }^{39} \mathrm{Ar}$ precise dating results of individual minerals in the eastern Jiaodong Peninsula [20].

\begin{tabular}{|c|c|c|c|c|c|}
\hline $\begin{array}{l}\text { Sample position and } \\
\text { sample number }\end{array}$ & Lithology & Minerals selected & Serial number & $\begin{array}{c}{ }^{40} \mathrm{Ar} /{ }^{39} \mathrm{Ar} \text { plateau } \\
\text { age, } \mathrm{Ma}\end{array}$ & $\begin{array}{c}\text { Tectonic setting of } \\
\text { samples }\end{array}$ \\
\hline Qiandao01120905 & Granite gneiss & Biotite & R03020 & $126.49 \pm 0.23$ & Shidao shear zone \\
\hline Beiqishan01121002 & Granite gneiss & Biotite & R03002 & $126.59 \pm 0.22$ & Shidao shear zone \\
\hline Daoxitou01121005 & Granite gneiss & Biotite & R03026 & $125.72 \pm 0.15$ & Shidao shear zone \\
\hline Dashijia01120908B & Granite gneiss & Biotite & R03005 & $188.96 \pm 0.50$ & Rongcheng nappe \\
\hline Dashijia01120908H & Granite gneiss & Hornblende & R03019 & $196.04 \pm 0.28$ & Rongcheng nappe \\
\hline Zetou01120807 & Granite mylonite & Muscovite & R03009 & $192.13 \pm 0.46$ & Mishan nappe \\
\hline Xilongjia01121101 & Granite gneiss & Biotite & R03008 & $124.20 \pm 0.21$ & Rongcheng shear zone \\
\hline Wanggezhuang01121504 & $\begin{array}{l}\text { Quartzofeldspathic } \\
\text { mylonite }\end{array}$ & Biotite & R03025 & $122.82 \pm 0.28$ & Mouping shear zone \\
\hline
\end{tabular}

$\sim 120 \mathrm{Ma}$, amazingly similar to those of the Dabie area. The two groups might represent the ages of the reversion of ultrahigh pressure metamorphic rocks during the postorogenic structural relaxation and the slip compressional deformation after the orogeny, respectively.

As well known, in the Early Cretaceous, almost the whole North China area was tectonically in an extensional or extruding setting. However, the large-scale sinistral strikeslipping of the Tan-Lu fault zone resulted in the sinistral strike-slipping compressional settings at least at the shallow part of the crust in the east side front of the Tan-Lu faults, to form the sinistral strike-slipping thrust nappes and the clockwise rotation of the blocks bounded by the shear zones. The subduction of the west Pacific plate toward NW and/or NNW resulted in the strike slipping and the northward movement at the east side of the Tan-Lu fault zone. Meanwhile, the deep part of the crust in the Jiaodong peninsula might be under the extensional tectonic background, according to the relative data of basins and volcanic rocks.

\section{Mesozoic Tectonic Dynamics in the Yanshan Area}

The Yanshan area, one famous intraplate orogen considered by some authors (e.g., [21, 22]), is located at the north part of the eastern NCB. The Yanshan area is the cradle of Chinese geologists. Since Wong [23] put forward "Yanshan Movement," lots of attentions have been paid by geologists in the aspect of the Mesozoic strong tectonic deformation and severe magma activities. In recent years, the Mesozoic complex intraplate deformation has become one major focus of continental dynamics research in China.

The eastern segment of the Yanshan area is characterized with two ductile shear zones trending EW and NNE respectively, which controlled the tectonic framework of the northern North China. Field observations and structural analyses reveal that the EW trending ductile shear zones are mainly contributed to dextral compressional deformation that resulted from top-to-the-southeast oblique thrust 


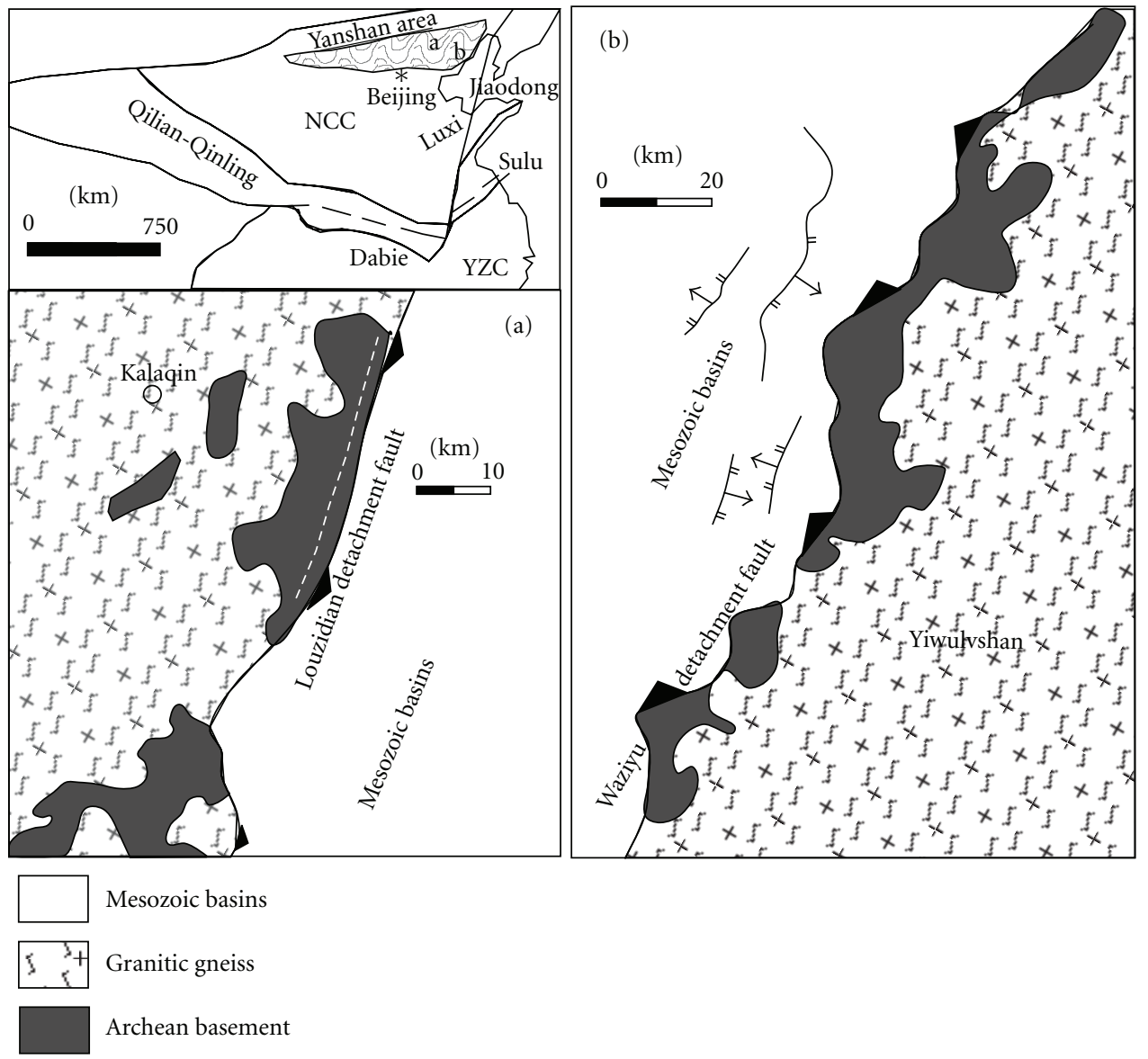

FIGURE 6: Geological map of the Eastern Yanshan Area. Simplified geological map showing major tectonic units of the Yanshan belt and its surrounding areas, with the locations of Kalaqin and Yiwulüshan metamorphic core complexes indicated by a rectangle. (a) Sketch geological map of the Kalaqin metamorphic core complex (modified after [29]); (b) Sketch geological map of the Yiwulüshan metamorphic core complex (adopted from [32]).

shearing, whereas the NNE trending ones are genetically related to sinistral strike slip and extensional faulting. The ${ }^{40} \mathrm{Ar} /{ }^{39} \mathrm{Ar}$ geochronology indicates that the top-to-thesoutheast oblique thrusting event recorded by the EWtrending ductile shear zones mainly occurred in Late Triassic (Yanshanian, too) [24]. Recent studies have clarified a series of major Mesozoic contractional events in the Yanshan area $[21,25]$. The Huairou thrust north of Beijing has overridden the Cambrian carbonates above the Middle Jurassic Tiaojishan formation $\left(\mathrm{J}_{2}\right)$ at Late Jurassic with a southern displacement direction. The Gubeikou-Pingquan fault features both south-vergent thrusting and dextral strike slipping with an age span from 148 to $132 \mathrm{Ma}$ [21]. In summary, the activity period for contraction and thrusting at the Yanshan tectonic belt are mainly concentrated at Late Triassic and Late Jurassic.

Similar to most orogens, localized regions of largemagnitude extensional strain typified by metamorphic core complexes are also prominent geologic and physiographic features of the Yanshan tectonic belt. The examples include the Yunmengshan metamorphic core complex north of Beijing [26-28], the Kalaqin metamorphic core complex in the
Inner Mongolia [29-31], and the Yiwulüshan metamorphic core complex in western Liaoning [31, 32].

As described by Han et al. [29] and Shao et al. [30], the Kalaqin metamorphic core complex is a major structural component of the Ma'anshan uplift with a length of about $100 \mathrm{~km}$ and a width of about $35 \mathrm{~km}$ (Figures 6(a) and $6(\mathrm{~b}))$. The core of the uplift consists of Archean gneisses of epidote-amphibolite facies $(>2.5 \mathrm{Ga})$, marbles and TTG series, Early Proterozoic schists and marbles of low green schist facies, Late Proterozoic Minganshan group slates, Cambrian carbonates, Early Permian-Middle Jurassic plutonic rocks, and Early Cretaceous granitic rocks. The eastern and western flanks of the uplift consist mainly of JurassicCretaceous terrestrial volcanic and sedimentary strata. The Louzidian detachment fault, which consists of the Louzidian ductile shear zone and the related Louzidian normal fault, separates metamorphosed complexes in the footwall to the west from the unmetamorphosed Mesozoic and Cenozoic sedimentary covers in the hanging wall. Field observations and structural analyses reveal that the ductile shear zone was genetically related to sinistral strike slip and extensional 
faulting. ${ }^{40} \mathrm{Ar} /{ }^{39} \mathrm{Ar}$ geochronology established an Early Cretaceous age for its formation [31].

As first reported by $\mathrm{Ma}$ et al. [33], geochronologically constrained by Zhang et al. [31] and further defined structurally by Darby et al. [32], the Yiwulüshan of western Liaoning displays many of the structural, metamorphic, and igneous features that characterize Cordilleran metamorphic core complexes. Situated along the eastern segment of the Yanshan area, the Yiwulüshan metamorphic core complex has an east-west dimension of $25 \mathrm{~km}$ and a north-south dimension of $60 \mathrm{~km}$ (Figure $6(\mathrm{c})$ ). The core consists predominantly of Mesozoic granitoid plutons and their country rocks, which include migmatite, epidote-amphibolite facies paragneiss, and orthogneiss of the Archean crystalline basement. Plutons are granodioritic to granitic and grade outward into augen gneiss or migmatite. At structurally higher levels, it is the well-developed NNE-trending Waziyu ductile shear which, together with the related normal fault above it along the eastern margin of the Fuxin basin, separates the core of the dome from the hanging wall of the unmetamorphosed to low-grade metamorphosed Middle-Late Proterozoic Changcheng System and the Mesozoic sedimentary and volcanic rocks. Three synkinematic biotites from the Waziyu ductile shear zone give a ${ }^{40} \mathrm{Ar} /{ }^{39} \mathrm{Ar}$ plateau age span of 130-116 Ma and thus establish its main activity period as Early Cretaceous [31, 32]. Zircon U-Pb geochronology indicates that three representative batholiths (Lüshan, Jianlazishan, and Hengshan) at the core were mainly emplaced during Middle-to-Late Jurassic times, with ages of 164, 153, and $153 \mathrm{Ma}$, respectively [34]. Four other mineral samples from the core and the eastern flank give ${ }^{40} \mathrm{Ar} /{ }^{39} \mathrm{Ar}$ ages of $133 \mathrm{Ma}$ (muscovite), $140 \mathrm{Ma}$ (biotite), $156 \mathrm{Ma}$ (K-feldspar), and $165 \mathrm{Ma}$ (hornblende), respectively, (unpublished data), indicting the extensional exhumation of the metamorphic core complex range from east to west.

As a case with the Basin and Range Province of the Western United States, the isolated metamorphic core complexes within the Yanshan area, such as the Yunmengshan, Kalaqin, and Yiwulüshan metamorphic core complexes, represent the high-strain extension regions within a broad region of more distributed extensional deformation during Early Cretaceous [25-27, 30, 33, 35-38]. Their formation are contributes to gravitational collapse of an orogenically thickened crust that was facilitated by thermal weakening due to localized deep-seated plutonism and paleo-Pacific plate boundary reorganization $[25,31,32]$.

\section{Discussion and Conclusion}

The statistics indicate that the main Mesozoic magmatic, metamorphic, and tectonic events on the Dabie, Luxi, Jiaodong, and Yanshan areas of the eastern NCB from south to north are consistent in time and genesis (Table 3, [39]). In the eastern NCB, the nearly S-N compression in Early Mesozoic dominated the formation of a series of thrusts trending almost E-W. In Cretaceous, the extension dominated the formation of a series of extensional detachment structures and metamorphic core complex. Many scholars had studied the tectonic setting of the tectonic regime inversion in eastern NCB and gotten different opinions [7, 15, 40-43]. On the base of our studies and former researches, this paper discusses this issue briefly.

5.1. The Early Mesozoic Compression Setting. In the south of the NCB, the Mesozoic compressions occurred in EarlyMiddle Triassic-early Late Jurassic, such as the Dabie and Luxi areas, but, in the north, occurred a little later, such as the Yanshan area which experienced two periods: in the Late Triassic and the Late Jurassic.

The collision between the Yangtze block and the NCB began at Middle-Late Triassic, the Dabie-Sulu ultrahigh pressure metamorphic belt was formed at 242-224 Ma and cooled down to $300^{\circ} \mathrm{C}$ at $180 \mathrm{Ma}[8,9]$, which is approximately consistent with the early deformation age of ductile shear zone in Dabie-Sulu orogenic belt (Ar-Ar age of $\sim 190$ Ma, Tables 1 and 2, $[11,18]$ ). Perhaps it was the geological record of orogenic relaxation at about 180-190 Ma, indicating the ending of collision orogenesis. The visual polar migration curve of NCB and Yangtze Block became consistency at $159 \mathrm{Ma}$ [10]. In general, the collision between the NCB and the Yangtze Block might cause the nearly S-N strong compression thrusting in the southern NCB in Middle Triassic-Middle Jurassic (240 Ma-180 Ma) [20, 44].

The compressive shortening in the northern NCB was mainly affected by the collisions of the Mongolia block with the NCB and the Siberia block with the North ChinaMongolia block. The collision time between the Mongolia block and the NCB was at about $250 \mathrm{Ma}-200 \mathrm{Ma}$. This collision caused nearly S-N compression and formed a series of E-W striking thrust nappes of 250-200 Ma in Yanshan area, such as the thrust-nappes thrusting southward at 219 Ma in Yiwulúshan. The Mongolia-Okhotsk paleoocean gradually closed eastward in Early-Middle Jurassic (190$170 \mathrm{Ma}$ ) and caused collision between the Siberia block and the North China-Mongolia block. The collision might keep on until Late Jurassic (160-150 Ma) and even later [42, 4548], which formed the Late Jurassic thrust-nappes thrusting southward in the Yanshan tectonic belt, such as the thrust nappes of the Cambrian overriding the Tiaojishan formation $\left(\mathrm{J}_{2-3}\right)$ in the Huaibei town of the Huairou area and the Gubeikou-Pingquan thrust fault in northern Beijing. During the relaxation period of compression, however, episodic extensional stress fields resulted in a series of Jurassic volcanic rocks.

5.2. Late Mesozoic Extensional Tectonic Setting. In the Late Mesozoic, the tectonic regime was inversed into extensional setting in the NCB. The extensions in the shallow crust were mainly displayed by extensional detachment faults and metamorphic core complex. The deformation age of extensional detachment shear zones in Yanshan tectonic belt is $140-100 \mathrm{Ma}$ with a peak period of $120-110 \mathrm{Ma}$, while in the Dabie and the Luxi area it is $130-110 \mathrm{Ma}$. The intrusion ages of the magmatic rocks in the metamorphic core complex mostly are 150-110 Ma, only a few reached $170-160 \mathrm{Ma}$, a little earlier than the detachment shear deformation on the 
TABle 3: Time-range index of main Mesozoic structure events in the eastern North China Block [39].

\begin{tabular}{|c|c|c|c|c|c|c|}
\hline \multirow{2}{*}{$\begin{array}{l}\text { Structure belt } \\
\text { Rock type }\end{array}$} & \multicolumn{3}{|c|}{ Dabie } & \multirow{2}{*}{$\begin{array}{l}\text { West Shandong } \\
\text { Intermediate- } \\
\text { mafic } \\
\text { rock }\end{array}$} & \multicolumn{2}{|c|}{ Yanshan } \\
\hline & (Ultra) mafic rocks & $\begin{array}{l}\text { Granite/shear } \\
\text { zone }\end{array}$ & $\begin{array}{c}\text { Metamorphic } \\
\text { rock } \\
\text { (migmatite) }\end{array}$ & & Intrusive & Shear zone \\
\hline $\begin{array}{l}\text { Isotopic age of compression } \\
\text { (Ma) }\end{array}$ & $220-240$ & 190 & $230-240$ & $230-250$ & $165-180$ & $\begin{array}{l}\sim 150 \\
\sim 219\end{array}$ \\
\hline $\begin{array}{l}\text { Isotopic age of extension } \\
(\mathrm{Ma})\end{array}$ & $120-130$ & $\sim 120$ & $117-130$ & $115-130$ & $111-130$ & $116-140$ \\
\hline $\begin{array}{l}\text { Structural index of } \\
\text { compression }\end{array}$ & \multicolumn{3}{|c|}{$\begin{array}{l}\text { The oldest deposit in foreland molasse basin is } \\
\text { Mid-Triassic and the youngest one is upper Jurassic }\end{array}$} & \multicolumn{3}{|c|}{$\gamma_{5}^{3}$ undeformed $\mathrm{J}_{2}$ or $\mathrm{J}_{3}$ (Tiaojishan group) deformed } \\
\hline $\begin{array}{l}\text { Structural index of } \\
\text { extension }\end{array}$ & & $\mathrm{J}_{3}, \gamma_{5}^{3}$ deformed & $\begin{array}{c}\mathrm{J}_{3} \text { or } \mathrm{K}_{1} \\
\text { deformed }\end{array}$ & \multicolumn{2}{|c|}{$\mathrm{K}_{1}$ deformed } & \\
\hline
\end{tabular}

whole. Though some areas such as Yanshan tectonic belt still show compression in shallow crust where thrust napping was developing, underplating and delamination had developed deeper.

It usually takes about tens to hundreds million years for deep underplating and delamination to exhibit extensional detachment structure in the shallow crust. Chronology and deformed rock strain data (such as the Dabie extensional detachment belt (Figure 3)) showed that magma intrusion directly caused extensional detachment. Some geologists related the extension to the NNW or NW subduction of the west Pacific plate into the Eurasia plate. Many evidences indicate that East-Asia circum-Pacific active continental margin began at Middle Jurassic (180 Ma), peaking at Late Jurassic-Early Cretaceous, equivalent to the B episode of the movement in the Yanshan area [42].

In Jurassic, the NCB was acted by three plates, such as the Yangtze, Siberian, and west Pacific plates, and with the orogenesis going on, the crust gradually thickened, potential energy difference increased, and the main compression stress gradually changed from horizontal to vertical. Especially with the thickening of the NCB crust, the lithosphere became unbalanced and the asthenosphere upwelled. Lithosphere underplating and delamination could cause lithosphere rebound; then partial melting, magma intrusion and volcanism occurred, which resulted in the uplift extension detachment of the crust. But whether the underplating and delamination in the eastern North China, beginning at Late Jurassic-Cretaceous, was related to the west Pacific plate subduction still needs to be further studied.

Some researchers suggested that the Late Mesozoic extensional tectonic setting in the eastern North China were mainly resulted from mantle branch structures [3-5, 49, 50]. This is a good way to interpret the Late Mesozoic thermal dome-extensional tectonic setting of the eastern North China According to the study of the PGE distributions, it was suggested that the mantle was rich in PGE at $120 \mathrm{Ma}$, which is apparently different from the previous PGE-deplete mantle. Therefore, we speculate that the materials from the earth core was added to the Late Mesozoic mantle (at least 8\%o, [15]), which supported the opinion of mantle branch structure to some degree.
In the Jiaodong peninsula, however, the sinistral strikeslip compressions dominated in Late Mesozoic, forming a series of thrust-nappes thrusting northward, and the deformation age of $\sim 120 \mathrm{Ma}$ (Table 2, [20]). The sinistral strike slipping of Jiaodong and the Tan-Lu faults could be related to the NE-ward subduction of the west Pacific plate. Therefore, sinistral strike-slip-compression stress field was generated in the east front of the Tan-Lu Faults zone, resulting in the sinistral strike-slip thrust faults and the clockwise rotation (at about $25^{\circ}$ ) of the blocks bounded by the thrust faults in the Jiaodong peninsula, similar to the Korea peninsula. Then deep structures could not be consistent with shallow ones and deep underplating and delamination; even magma intrusion and volcanism could have happened, but they were not immediately displayed in the shallow. It also suggested that the Tan-Lu Faults zone could be an important tectonic boundary, which caused significant difference in Mesozoic tectonic setting on the both sides of the Tan-Lu Faults.

\section{Acknowledgments}

The authors would like to thank Professor Jiliang Li, Professor Wenjiao Xiao, Professor Mingguo Zhai, and Professor Zhihong Wang from Institute of Geology and Geophysics, Chinese Academy of Sciences, and Dr. Tianshan Gao from university of Science and Technology of China for their kind help in field work and discussion. This work has been supported by the following grants: the National Natural Science Foundation of China (Grants 41030422; 90714003).

\section{References}

[1] S. Hu, Y. Zao, Z. Hu, J. Guo, and B. Xu, "Evolution and development of tectonics and magmatism at the active continental margin of east China (E 106 ${ }^{\circ}$ ) during Mesozoic and Cenozoic," Acta Petrologica Sinica, vol. 10, no. 4, pp. 370-381, 1994 (Chinese).

[2] J. S. Ren, B. G. Niu, and J. Zheng, "Tectonic frame and geodynamic evolution of eastern China," Geological Research, vol. 29, no. 30, pp. 43-55, 1997 (Chinese).

[3] J. F. Deng, H. L. Zhao, and X. X. Mo, Continental Roots-Plume Tectonics of China, Beijing, China, Geological Publishing House, 1996. 
[4] J. Deng, S. Su, Y. Niu et al., "A possible model for the lithospheric thinning of North China Craton: evidence from the Yanshanian (Jura-Cretaceous) magmatism and tectonism," Lithos, vol. 96, no. 1-2, pp. 22-35, 2007.

[5] S. V. Lysak, "Thermal history, geodynamics, and current thermal activity of lithosphere in China," Russian Geology and Geophysics, vol. 50, no. 9, pp. 815-825, 2009.

[6] M. Zhai, J. Yang, and W. Liu, "The large-scale metallogenesis and large-scale cluster of gold-deposits in eastern Shandong, China," Science in China D, vol. 44, no. 8, pp. 758-768, 2001.

[7] M. Zhai, R. Zhu, J. Liu et al., "Time range of Mesozoic tectonic regime inversion in eastern North China Block," Science in China D, vol. 47, no. 2, pp. 151-159, 2004.

[8] B. R. Hacker, L. Ratschbacher, L. Webb, T. Ireland, D. Walker, and $\mathrm{D}$. Shuwen, "U/Pb zircon ages constrain the architecture of the ultrahigh-pressure Qinling-Dabie Orogen, China," Earth and Planetary Science Letters, vol. 161, no. 1-4, pp. 215230, 1998.

[9] L. Ratschbacher, B. R. Hacker, A. Calvert et al., "Tectonics of the Qinling (Central China): tectonostratigraphy, geochronology, and deformation history," Tectonophysics, vol. 366, no. 12, pp. 1-53, 2003.

[10] S. A. Gilder, P. H. Leloup, V. Courtillot et al., "Tectonic evolution of the Tancheng-Lujiang (Tan-Lu) fault via Middle Triassic to Early Cenozoic paleomagnetic data," Journal of Geophysical Research B, vol. 104, no. 7, pp. 15365-15390, 1999.

[11] Q. Hou, Q. Liu, J. Li, and H. Zhang, "Late Mesozoic shear zones and its chronology in the Dabie Mountains, Central China," Scientia Geologica Sinica, vol. 42, no. 1, pp. 114-123, 2007.

[12] S. W. Dong, J. M. Hu, S. Z. Li et al., "The Jurassic deformation in the Dabie Mountains and its tectonic significances," Acta Petrologica Sinica, vol. 21, no. 4, pp. 1189-1194, 2005.

[13] S. Suo, Z. Zhong, and Z. You, "Extensional deformation of post ultrahigh-pressure metamorphism and exhumation process of ultrahigh-pressure metamorphic rocks in the Dabie massif, China," Science in China D, vol. 43, no. 3, pp. 225-236, 2000.

[14] Q. Liu, Study on the distribution of Platinum group elements in Dabie (ultra-) mafic rocks and Fuxin volcanic rocks [Ph.D. dissertation], Graduate University of the Chinese Academy of Sciences, Beijing, China, 2005.

[15] Q. Liu, Q. L. Hou, X. H. Zhou, and L. W. Xie, "The distribution of platinum-group elements in gabbros from Zhujiapu, Dabie orogen," Acta Petrologica Sinica, vol. 21, no. 1, pp. 227239, 2005.

[16] M. Zhai, J. Guo, Q. Wang, K. Ye, B. Cong, and W. Liu, "Division of petrological-tectonic units in the Northern Sulu ultra high pressure zone: an example of thick-skin thrust of crystalline units," Scientia Geologica Sinica, vol. 35, no. 1, pp. 16-26, 2000 (Chinese).

[17] M. Yang and G. Lü, The Geology-Geochemistry of Gold Deposits of the Greenstone Belt in Jiaodong District, China, Geological Publishing House, Beijing, China, 1996.

[18] H. Y. Zhang, Q. L. Hou, and D. Y. Cao, "Study of thrust and nappe tectonics in the eastern Jiaodong Peninsula, China," Science in China D, vol. 50, no. 2, pp. 161-171, 2007.

[19] X. X. Zhao, R. S. Coe, H. K. Chang et al., "Clockwise rotations recorded in Early Cretaceous rocks of South Korea: Implications for tectonic affinity between the Korea Peninsula and North China," Geophysical Journal International, vol. 139, no. 2, pp. 447-463, 1999.

[20] H. Y. Zhang, Q. L. Hou, and D. Y. Cao, "Tectono-chronologic constraints on a Mesozoic slip and thrust belt in the eastern
Jiaodong Peninsula," Science in China D, vol. 50, no. 1, pp. 2532, 2007.

[21] C. Zhang, G. Wu, D. Xu, G. Wang, and W. Sun, "Mesozoic tectonic framework and evolution in the central segment of the intraplate Yanshan orogenic belt," Geological Bulletin of China, vol. 23, no. 9-10, pp. 864-875, 2004 (Chinese).

[22] J. Hu, X. Liu, Y. Zhao, G. Xu, J. Liu, and S. Zhang, "On Yanshan intraplate orogene: an example from Taiyanggou area, Lingyuan, Western Liaoning Province, Northeast China," Earth Science Frontiers, vol. 11, no. 3, pp. 255-271, 2004 (Chinese).

[23] W. H. Wong, "Crustal movements and igneous activities in eastern China since Mesozoic time," Bulletin of the Geological Society of China, vol. 6, no. 1, pp. 9-37, 1927.

[24] X. Zhang, T. Li, and Z. Pu, " ${ }^{40} \mathrm{Ar} /{ }^{39} \mathrm{Ar}$ thermochronology of two ductile shear zones from Yiwulüshan, West Liaoning Region: age constraints on the Mesozoic tectonic events," Chinese Science Bulletin, vol. 47, no. 13, pp. 1113-1118, 2002.

[25] G. A. Davis, Y. Zheng, C. Wang, B. J. Darby, C. Zhang, and G. E. Gehrels, "Mesozoic tectonic evolution of the Yanshan fold and thrust belt, with emphasis on Hebei and Liaoning provinces, northern China," in Paleozoic and Mesozoic Tectonic Evolution of Central and Eastern Asia: From Continental Assembly to Intracontinental Deformation, M. S. Hendrix and G. A. Davis, Eds., vol. 194 of Geological Society of America Memoir, pp. 171-197, 2001.

[26] G. A. Davis, X. Qian, Y. Zheng et al., "The Huairou (Shuiyu) ductile shear zone, Yunmengshan Mts." in Proceedings of the 30th international Geological Congress Field Trip Guide, Beijing Geological Publishing House, Beijing, China, 1996.

[27] G. A. Davis, X. Qian, Y. Zheng et al., "Mesozoic deformation and plutonism in the Yunmengshan: a Chinese metamorphic core complex north of Beijing, China," in The Tectonic Evolution of Asia, A. Yin and T. M. Harrison, Eds., pp. 253-280, Cambridge University Press, Cambridge, UK, 1996.

[28] G. A. Davis, Y. Zheng, C. Wang, B. J. Darby, C. Zhang, and G. E. Gehrels, "Geometry and geochronology of Yanshan belt tectonics," in Proceedings of the 100th Anniversary Celebration of Peking University: Collected Works of International Symposium on Geological Science, pp. 275-292, Department of Geology, Peking University, Beijing, China, 1998.

[29] B. F. Han, Y. Zheng, J. Gan, and Z. Chang, "The Louzidian normal fault near Chifeng, inner Mongolia: master fault of a quasi-metamorphic core complex," International Geology Review, vol. 43, no. 3, pp. 254-264, 2001.

[30] J. A. Shao, L. Q. Zhang, W. Jia, and P. Y. Wang, "Harkin metamorphic core complex in Inner Mongolia and its upwelling mechanism," Acta Petrologica Sinica, vol. 17, no. 2, pp. 283290, 2001 (Chinese).

[31] X. Zhang, H. Wang, and Y. Ma, ${ }^{40} \mathrm{Ar} /{ }^{39} \mathrm{Ar}$ age constraints on two NNE-trending ductile shear zones, Yanshan intraplate Orogen, North China Craton," International Geology Review, vol. 45, no. 10, pp. 936-947, 2003.

[32] B. J. Darby, G. A. Davis, X. Zhang, F. Wu, S. Wild, and J. Yang, "The newly discovered Wuziyu metamorphic core complex, Yiwulü Shan, western Liaoning province, North China," Earth Science Frontiers, vol. 11, no. 3, pp. 145-155, 2004.

[33] Y. Ma, S. Cui, G. Wu et al., "The structural feature of metamorphic core complex in Yiwulüshan mountains, western Liaoning," Acta Geoscientia Sinica, vol. 20, pp. 385-391, 1999 (Chinese). 
[34] X. H. Zhang, Q. Mao, H. F. Zhang, and S. A. Wilde, "A Jurassic peraluminous leucogranite from Yiwulüshan, western Liaoning, North China craton: age, origin and tectonic significance," Geological Magazine, vol. 145, no. 3, pp. 305-320, 2008.

[35] G. A. Davis, B. J. Darby, Y. Zheng, and T. L. Spell, "geometric and temporal evolution of an extensional detachment fault, Hohhot metamorphic core complex, Inner Mongolia, China," Geology, vol. 30, pp. 1003-1006, 2002.

[36] L. E. Webb, S. A. Graham, C. L. Johnson, G. Badarch, and M. S. Hendrix, "Occurrence, age, and implications of the Yagan-Onch Hayrhan metamorphic core complex, southern Mongolia," Geology, vol. 27, no. 2, pp. 143-146, 1999.

[37] C. L. Johnson, L. E. Webb, S. A. Graham, M. S. Hendrix, and G. Badarch, "Sedimentary and structural records of Late Mesozoic high-strain extension and strain partitioning, east Gobi basin, Southern Mongolia," in Paleozoic and Mesozoic Tectonic Evolution of Central and Eastern Asia: From Continental Assembly to Intracontinental Deformation, M. S. Hendrix and G. A. Davis, Eds., vol. 194 of Geological Society of America Memoir, pp. 413-433, 2001.

[38] J. Ren, K. Tamaki, S. Li, and Z. Junxia, "Late Mesozoic and Cenozoic rifting and its dynamic setting in Eastern China and adjacent areas," Tectonophysics, vol. 344, no. 3-4, pp. 175-205, 2002.

[39] Q. L. Hou, Y. D. Wu, F. Y. Wu, M. G. Zhai, J. H. Guo, and Z. Li, "Possible tectonic manifestations of the Dabie-Sulu orogenic belt on the Korean Peninsula," Geological Bulletin of China, vol. 27, no. 10, pp. 1659-1666, 2008.

[40] M. Zhai, R. Zhu, J. Liu et al., "Time range of Mesozoic tectonic regime inversion in eastern North China Block," Science in China D, vol. 33, no. 10, pp. 913-920, 2003.

[41] Y. Zhao, Z. Yang, and X. Ma, "Geotectonic transition from Paleoasian system and Paleotethyan system to Paleopacific active continental margin in eastern Asia," Scientia Geologica Sinica, vol. 29, no. 2, pp. 105-119, 1994.

[42] Y. Zhao, G. Xu, S.-H. Zhang et al., "Yanshanian movement and conversion oftectonic regimes in East Asia," Earth Sciences Frontiers, vol. 11, no. 3, pp. 319-328, 2004.

[43] Z. Yadong, G. A. Davis, W. Cong, B. J. Darby, and Z. Changhou, "Major Mesozoic tectonic events in the Yanshan belt and the plate tectonic setting," Acta Geologica Sinica, vol. 74, no. 4, pp. 289-302, 2000.

[44] R. Y. Zhang, J. G. Liou, and W. G. Ernst, "The Dabie-Sulu continental collision zone: a comprehensive review," Gondwana Research, vol. 16, no. 1, pp. 1-26, 2009.

[45] A. M. Ziegler, P. M. Ree, D. B. Rowley, A. Bekker, Q. Li, and M. Hulver, "Mesozoic assembly of Asia: constraints from fossil floras. Tectonics, and paleomagnetism," in Tectonic Evolution of Asia, T. M. A. Harrison, Ed., pp. 371-400, Cambridge University Press, Cambridge, UK, 1996.

[46] A. Yin and S. Nie, "A Phanerozoic palinspastic reconstruction of China and its neighboring regions," in Tectonic Evolution of Asia, A. Yin and T. M. Harrison, Eds., pp. 442-485, Cambridge University Press, Cambridge, UK, 1996.

[47] L. Zonenshain, M. Kuzmin, and L. Natapov, Geology of RSSR: A Plate Tectonic Synthesis, vol. 21 of Geodynamic Series, American Geophysical Union, Washington, DC, USA, 1990.

[48] Q. R. Meng, "What drove late Mesozoic extension of the northern China-Mongolia tract?" Tectonophysics, vol. 369, no. 3-4, pp. 155-174, 2003.

[49] S. Niu, Z. Hou, and A. Sun, "The anti-gtavityu migration of metallogenic fluid from core and mantle," Earth Science Frontiers, vol. 8, no. 3, pp. 95-101, 2001.
[50] J. Zheng, S. Y. O’Reilly, W. L. Griffin, F. Lu, M. Zhang, and N. J. Pearson, "Relict refractory mantle beneath the eastern North China block: significance for lithosphere evolution," Lithos, vol. 57, no. 1, pp. 43-66, 2001. 

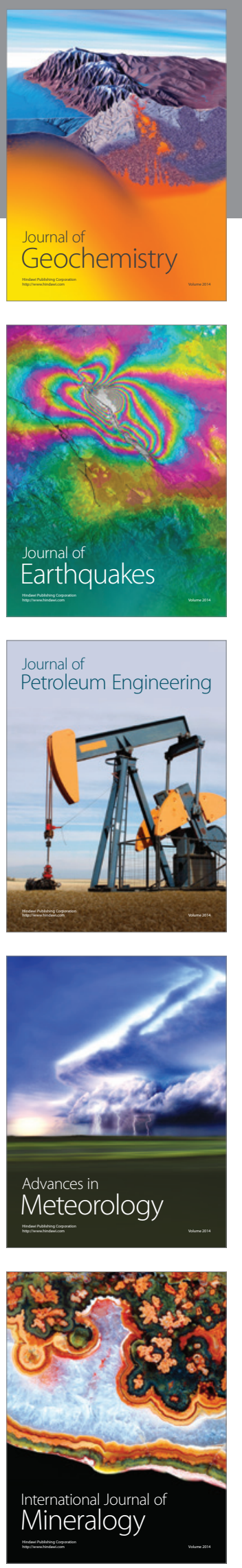
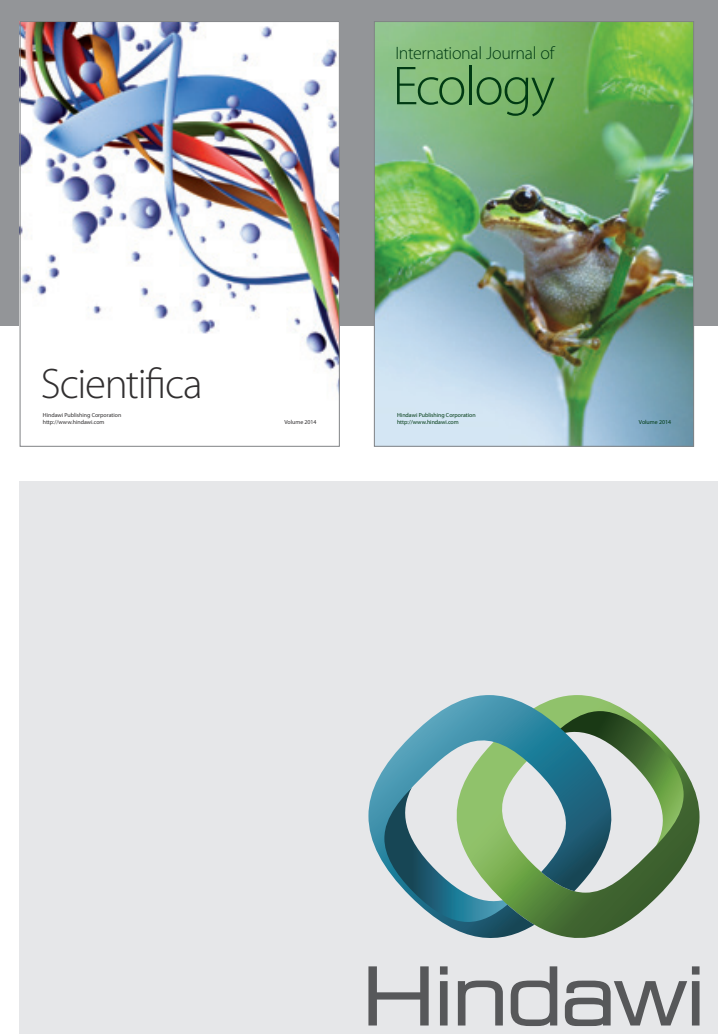

Submit your manuscripts at http://www.hindawi.com
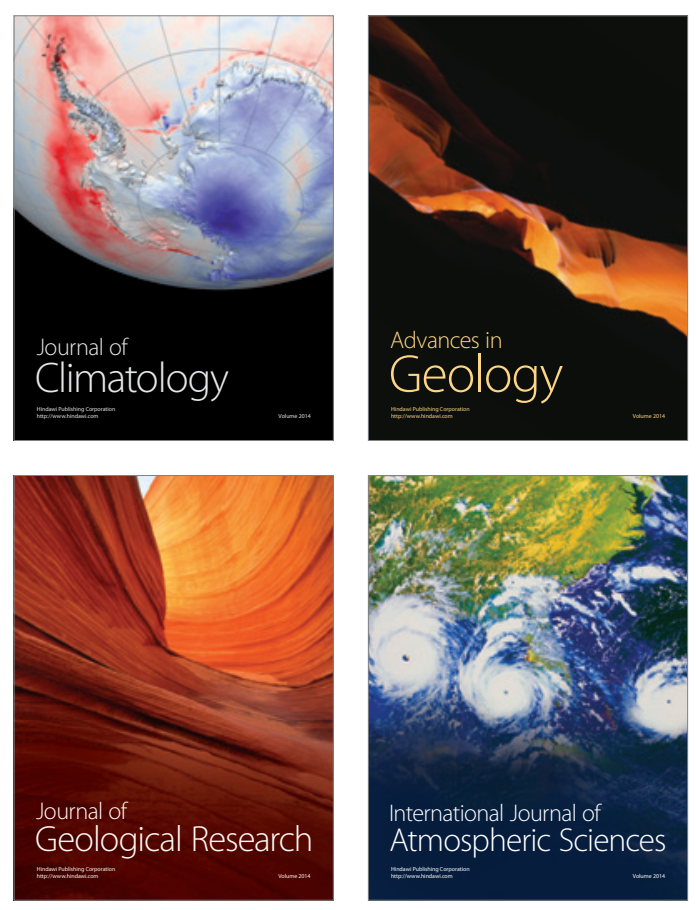
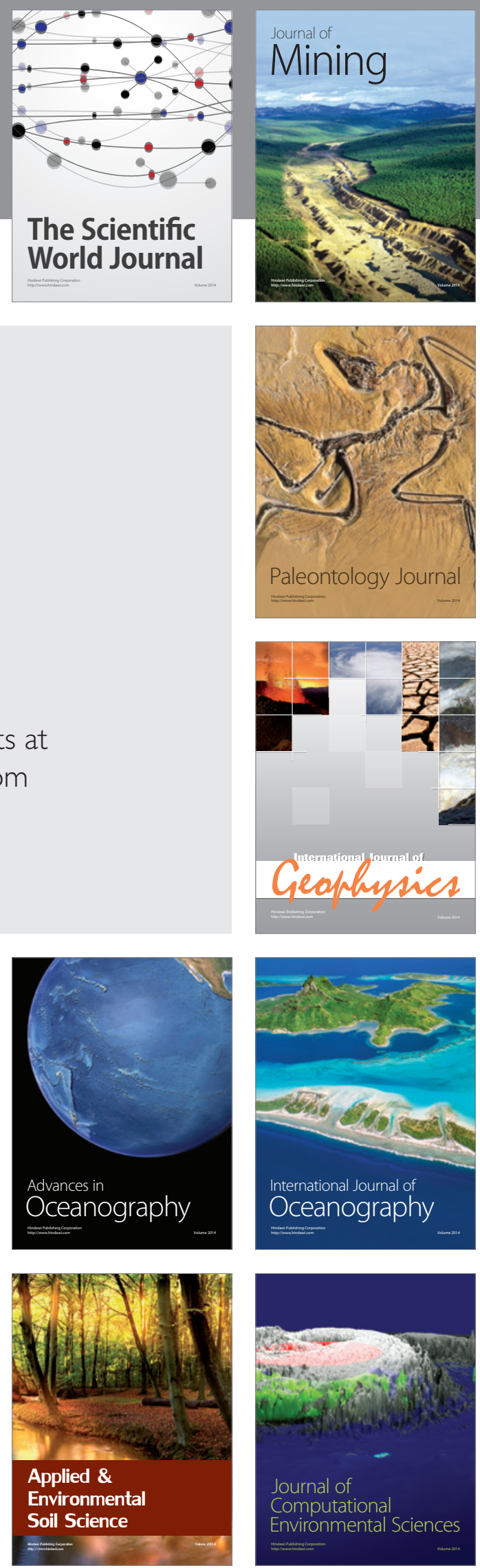